\title{
Dendritic cell-based multi-epitope immunotherapy of hormone-refractory prostate carcinoma
}

\begin{abstract}
Background: Dendritic cell (DC)-based immunotherapy is a promising approach to augment tumor antigen-specific $\mathrm{T}$ cell responses in cancer patients. However, tumor escape with down-regulation or complete loss of target antigens may limit the susceptibility of tumor cells to the immune attack. Concomitant generation of $\mathrm{T}$ cell responses against several immunodominant antigens may circumvent this potential drawback. In this trial, we determined the immunostimulatory capacity of autologous DC pulsed with
\end{abstract}

Grant sponsors: Cancer League St. Gallen-Appenzell; Swiss Cancer League; Foundation Propter Homines Vaduz Liechtenstein; Cancer Research Institute USA; Foundation for Clinical Cancer Research of Eastern Switzerland (OSKK)

Y. Waeckerle-Men · E. Uetz-von Allmen · B. Ludewig

M. Groettrup

Research Department, Cantonal Hospital St. Gallen,

9007 St. Gallen, Switzerland

M. Fopp

Blood bank, Red Cross St. Gallen, Cantonal Hospital St. Gallen, 9007 St. Gallen, Switzerland

R. von Moos $\cdot$ C. Böhme $\cdot$ T. Cerny $\cdot$ S. Gillessen $(\square)$

Oncology Department, Cantonal Hospital St. Gallen,

9007 St. Gallen, Switzerland

E-mail: silke.gillessen@kssg.ch

Tel.: + 41-71-4941092

Fax: + 41-71-4946325

H.-P. Schmid

Urology Department, Cantonal Hospital St. Gallen,

9007 St. Gallen, Switzerland

D. Ackermann

Urology Department, Hirslandenklinik, 5001 Aarau, Switzerland

M. Groettrup

Department of Biology, Division of Immunology,

University of Constance, 78457 Konstanz, Germany

M. Groettrup

Biotechnology Institute Thurgau, 8274 Tägerwilen, Switzerland multiple $\mathrm{T}$ cell epitopes derived from four different prostate-specific antigens in patients with advanced hormone-refractory prostate cancer. Patients and methods: Autologous DC of HLA-A* $0201^{+}$patients with hormone-refractory prostate cancer were loaded with antigenic peptides derived from prostate stem cell antigen (PSCA $14-22)$, prostatic acid phosphatase $\left(\mathrm{PAP}_{299}\right.$ 307), prostate-specific membrane antigen (PSMA $4-12$ ), and prostate-specific antigen ( $\left.\mathrm{PSA}_{154-163}\right)$. DC were intradermally applied six times at biweekly intervals followed - in the case of an enhanced immune response-by monthly booster injections. Immune monitoring during the time of ongoing vaccinations (1259 weeks) included ex vivo ELISPOT measurements, MHC tetramer analysis and in vitro cytotoxicity assays. Results: Of the initial six patients, three qualified for long-term multi-epitope DC vaccination. This regime was tolerated well by all three patients. The vaccination elicited significant cytotoxic $\mathrm{T}$ cell responses against all prostate-specific antigens tested. In addition, memory $T$ cell responses against the control peptides derived from influenza matrix protein and tetanus toxoid were efficiently boosted. Clinically, the long-term DC vaccination was associated with an increase in PSA doubling time. Conclusions: DC-based multi-epitope immunotherapy with repeated boosting in men with hormonerefractory prostate carcinoma is feasible and generates efficient cellular antitumor responses.

Keywords Hormone-refractory prostate carcinoma · Clinical trial $\cdot$ Dendritic cells $\cdot$ Cancer vaccine $\cdot$ Immune monitoring

Abbreviations CTL: Cytotoxic $\mathrm{T}$ lymphocytes $\cdot \mathrm{DC}$ : Dendritic cells - GM-CSF: Granulocyte-macrophage colony-stimulating factor $\cdot$ IL: Interleukin $\cdot \mathrm{mAb}$ : Monoclonal antibody - PAP: Prostatic acid phosphatase - PBMC: Peripheral blood mononuclear cells · PSA: Prostate-specific antigen - PSCA: Prostate stem cell antigen - PSMA: Prostate-specific membrane antigen 


\section{Introduction}

Prostate cancer is a major cause of morbidity and mortality in men in the Western World. Early stage treatment - prostatectomy and radiation therapy-is efficient in roughly $80 \%$ of the cases [1], whereas promising strategies for hormone-refractory disease are limited. For example, taxane-based chemotherapy provides a modest survival benefit of a few months but is associated with significant side effects $[2,3]$. All the treatments for hormone-refractory prostate cancer are palliative and the median survival time for these patients is still below 2 years. There is thus a strong need for novel, well-tolerated treatment strategies.

Antitumor vaccination is considered a promising means to induce systemic immunity against malignant cells and to reduce tumor cell load both during early and metastatic prostate cancer [4]. The generation of vaccines as described in this study relies first on the identification of suitable antigens and, second, on their delivery to secondary lymphoid organs where they need to be presented by dendritic cells (DC). It has been shown that the DC-based vaccines are well suited to induce significant immune responses against prostatespecific membrane antigen (PSMA) [5, 6], prostate-specific antigen (PSA) [7], prostatic acid phosphatase (PAP) [8-10], or telomerase reverse transcriptase (TERT) [11, 12]. Tumor cells may evade immune recognition by down-regulation of antigen expression [13] or by altering antigen processing [14]. Multi-epitope vaccination may overcome this potential limitation by maintaining immunological pressure against different tumor-associated antigens.

A second important consideration for successful DCbased vaccination is the need for sustained $\mathrm{T}$ cell activity in order to prevail in the constant uphill struggle against the growing tumor mass. The basis for this notion is the loss of immediate $\mathrm{T}$ cell activity in the absence of appropriate restimulation [15]. Reactivation of memory $\mathrm{T}$ cell activity is best achieved if the antigen is presented by DC $[16,17]$. This trial evaluated a multi-epitope DC vaccination with repeated boosting in men with hormone-refractory prostate carcinoma, to test the hypothesis that this approach is feasible and generates efficient cellular antitumor responses.

\section{Patients, materials and methods}

Patients

Patients with hormone-refractory prostate cancer were eligible for enrolment if disease progression was documented. For PSA progression, two consecutive increases in serum levels of PSA had to be documented. In the case of therapy with anti-androgens, these had to have been stopped at least 6 weeks before enrolment. Previous radiotherapy was allowed if it had been stopped at least 4 weeks before enrolment. Other eligibility requirements included: an Eastern Cooperative Oncology Group performance status of 0,1 or 2 , an estimated life expectancy $\geq 3$ months, age $\geq 18$ years, an ejection fraction of $>40 \%$ as measured by echocardiography, and the absence of concurrent steroid therapy, uncontrolled infections, severe autoimmune diseases and other malignancies. This phase I/II trial received approval from the Regional Ethical Committee and all patients provided written informed consent.

Six patients with hormone-refractory prostate cancer were enrolled into this phase I/II trial between July 2003 and December 2004. The median age was 71.5 with a range from 58 to 74 years (Table 1). One patient had PSA progression and a local relapse, five patients had PSA progression and bone metastases, and one patient had PSA-progression, bone metastases, a prostatic tumor and lymph node metastases. All patients had androgen ablation either by orchiectomy or by continued application of LHRH analogs. Three patients had received a second hormonal manipulation by an antiandrogen, one patient had received PC-SPES and a second patient had been treated with Samarium. One patient had been treated with Estramustine before entering the trial (Table 1).

\section{Cell culture reagents and materials}

AIM-V medium was purchased from Invitrogen (Groningen, the Netherlands). RPMI and DMEM cell culture media were obtained either from Invitrogen (Groningen, the Netherlands) or from Sigma (Taufkirchen, Germany). Human AB serum was bought from Cambrex Bio Science (Walkersville, MD, USA). FicollPaque was obtained from Pharmacia (Uppsala, Sweden). GMP human recombinant cytokines interleukin (IL)- $4, \mathrm{TNF}-\alpha$, IL-1 $\beta$, and IL-6 were purchased from

Table 1 Patients' characteristics at study entry

\begin{tabular}{lll}
\hline Characteristics & & Number of patients $(n=6)$ \\
\hline $\begin{array}{l}\text { Age (years) } \\
\text { Median }\end{array}$ & 71.5 & \\
Range & $58-74$ & \\
PSA $(\mu \mathrm{g} / \mathrm{l})$ & & \\
Median & 68.5 & \\
Range & $15-649$ & \\
Prior treatment & & \\
Prostatectomy & & 0 \\
Radiotherapy & & $(\mathrm{P} 04,09,16,24)$ \\
Estramustine & $1(\mathrm{P} 04)$ \\
Samarium & $1(\mathrm{P} 12)$ \\
LHRH analog & & $5(\mathrm{P} 04,07,12,16,24)$ \\
Orchiectomy & & $2(\mathrm{P} 09,16)$ \\
Antiandrogen & & $3(\mathrm{P} 04,16,24)$ \\
PC-SPES & $1(\mathrm{P} 07)$ \\
Site of metastases & & $5(\mathrm{P} 04,07,09,12,16)$ \\
Bone & $1(\mathrm{P} 09)$ \\
Lymph nodes & & $2(\mathrm{P} 09,24)$ \\
Prostatic tumor & & \\
\hline
\end{tabular}


CellGenix (Freiburg, Germany). Recombinant human granulocyte-macrophage colony-stimulating factor (GM-CSF) (Leukine Sargramostim) was obtained from Immunex (Seattle, WA, USA). Prostaglandin E2 (Prostin E2) was obtained from Pharmacia \& Upjohn (Dübendorf, Switzerland). Human chemokines CCL19 and CCL21 were bought from R\&D Systems (Wiesbaden-Nordenstadt, Germany). Tetanus toxoid (TT) was provided by Berna Biotech (Berne, Switzerland). HLAA*0201-restricted peptides FluM ${ }_{58-66}$ (Influenza A M1 protein 58-66), PSCA $_{14-22}, \mathrm{PAP}_{299-307}, \mathrm{PSMA}_{4-12}$, and $\mathrm{PSA}_{154-163}$, respectively, were synthesized by Dr. P. Henklein (Berlin, Germany).

\section{HLA-A2 typing}

The HLA-A2 haplotype of the patients was determined by flow cytometry using either FITC-conjugated mouse anti-human HLA-A2 monoclonal antibody (mAb) (BD Biosciences Pharmingen, San Diego, CA) or the mAb IGG-A2 (Ingen SA, Rungis Cedex, France) and sheep anti-mouse Ig $(\mathrm{H}+\mathrm{L})$ FITC-conjugated $\mathrm{F}\left(\mathrm{ab}^{\prime}\right)_{2}$ (Silenus, Melbourne, Australia). PCR typing for HLAA*0201 was performed with genomic DNA obtained from peripheral blood mononuclear cell (PBMC) pellets using a salting out procedure after SDS lysis and proteinase $\mathrm{K}$ treatment. PCR conditions were as described previously [18].

\section{Generation of dendritic cells and vaccination}

DC were generated from monocytes isolated from PBMC of prostate carcinoma patients essentially as described previously [19]. Briefly, buffy coats were collected by leukapheresis with Haemonetics $\mathrm{MCS}^{+}$at a recruitment speed of $50-70 \mathrm{ml} / \mathrm{min}$ for $2-4 \mathrm{~h}$. Buffy coats $\left(30-50 \mathrm{ml}\right.$ per patient containing on average $10^{9}$ PBMC) were diluted in Dulbecco's PBS w/o $\mathrm{Ca}^{2+}$ and $\mathrm{Mg}^{2+}$ (Vitromex, Germany) at a ratio of about 1:20. PBMC were further purified by Ficoll-Paque density gradient centrifugation at $700 \mathrm{~g}$ for $20 \mathrm{~min}$ and washed three times with PBS. One part of the obtained PBMC $\left(2-4 \times 10^{8}\right)$ was aliquoted and cryopreserved for subsequent immune monitoring. The remaining PBMC were resuspended in AIM-V medium at $6 \times 10^{6}$ per ml and seeded to $150 \mathrm{~cm}^{2}$ tissue culture flasks (TPP, Switzerland) for $1.5-2 \mathrm{~h}$ at $37^{\circ} \mathrm{C}$ for monocyte adherence. Non-adherent cells were removed by washing with PBS and adherent monocytes were further cultured in DCmedium (AIM-V containing $1,000 \mathrm{U} / \mathrm{ml}$ of GM-CSF and $800 \mathrm{U} / \mathrm{ml}$ of IL-4). DC-medium was replaced on days 3 and 5 with the addition of $20 \mathrm{ng} / \mathrm{ml}$ of TNF- $\alpha$, $10 \mathrm{ng} / \mathrm{ml}$ of IL- $1 \beta, 1,000 \mathrm{U} / \mathrm{ml}$ of IL-6 and $1 \mu \mathrm{g} / \mathrm{ml}$ of $\mathrm{PGE}_{2}$ at the latter time point to initiate DC maturation. Mature DC were pulsed on day 6 with $10 \mu \mathrm{g} / \mathrm{ml}$ TT for further $24 \mathrm{~h}$ in maturation medium. The yield of mature DC was $10-15 \%$ based on the numbers of PBMC collected. Fresh DC were prepared immediately for the first vaccination, the remaining cells were cryopreserved for further vaccinations and thawed with a viability of $70-80 \%$ as detailed elsewhere [19]. Fresh and thawed DC from each patient were examined for bacterial and fungal contamination by the Institute for Clinical Microbiology and Immunology, Cantonal Hospital St. Gallen.

A total number of $5 \times 10^{6}$ autologous thawed or fresh DC was prepared for each vaccination. A total number of $1 \times 10^{6}$ DC were pulsed with $10 \mu \mathrm{g} / \mathrm{ml}$ of FluM $_{58-66}$ peptide, and $4 \times 10^{6} \mathrm{DC}$ were pulsed with a pool of the peptides $\mathrm{PSCA}_{14-22}, \mathrm{PAP}_{299-307}, \mathrm{PSMA}_{4-12}$, and PSA $_{154-163}$ at a concentration of $10 \mu \mathrm{g} / \mathrm{ml}$ of each peptide. Cells were incubated for $1.5-2 \mathrm{~h}$ at $37^{\circ} \mathrm{C}$, washed once with $10 \mathrm{ml}$ PBS, the differently peptide pulsed DC were pooled and washed again. After the last washing step, the cell pellets were resuspended in $1.2 \mathrm{ml}$ of $0.9 \%$ $\mathrm{NaCl}$ injection solution and kept on ice.

Vaccines were injected intradermally $(6 \times 0.2 \mathrm{ml})$ in the inguinal region, i.e. 3 i.d. injections were performed each at the left and right upper thighs. The treatment scheme consisted of six immunizations every other week followed by monthly booster injections until the patient was taken off study. The total number of injections at the time of evaluation was 18 (P12), 12 (P16) and 11 (P04), respectively. Patients were restaged after 12 and 20 weeks and then at 3-month intervals or when clinically indicated. Responding, clinically stable, or indolent patients showing immunological responses to the vaccine qualified for additional vaccinations.

\section{Phenotypical characterization of dendritic cells}

Cells were stained with the following $\mathrm{mAbs}$ according to the manufacturer's protocols: FITC-labeled anti-human CD11c, CD14, CD16, CD20, CD40, DC-SIGN, CD80, CD83, CD86, HLA-DR and macrophage mannose receptor (MNR) (BD Biosciences). The respective isotype controls were FITC-labeled mouse IgG1, IgG2a or IgG2b. Staining for CCR7 was performed with a rat anti-human mAb (clone 3D12), kindly provided by Dr. R. Förster, Institute of Immunology, Hannover Medical School, Germany, followed by FITC-conjugated goatanti-rat IgG (Jackson Immunoresearch, La Roche, Switzerland). Cells were analyzed with a FACScalibur flow cytometer using CellQuest software (BD Biosciences).

The production of cytokines (TNF- $\alpha$, IL-10, IL12p70) by mature human DC has been described elsewhere [20]. The capacity of matured DC to migrate in a CCR7-dependent manner was measured by an in vitro chemotaxis assay as previously described [19]. Each experiment was performed in duplicate. The percentage of migrated cells was calculated as follows: \% migrated $\mathrm{DC}=$ (number of migrated $\mathrm{DC} /$ number of total DC) $\times 100 \%$. Values are given as the mean percentage of migrated cells \pm SEM. 


\section{Delayed-type hypersensitivity}

A number of $2 \times 10^{5}$ autologous DC were either left unpulsed or were loaded with FluM $_{58-66}$ peptide or TT or a mix of four prostate cancer specific peptides $\left(\mathrm{PSCA}_{14-22}\right.$, $\mathrm{PAP}_{299-307}$, $\mathrm{PSMA}_{4-12}$, and $\mathrm{PSA}_{154-163}$ ) and injected intradermally at the forearms at the time of the first, fourth, and sixth vaccination. The skin tests were read 48-72 $\mathrm{h}$ after administration. The widest diameter of distinctly palpable induration was recorded in millimeters. A $5 \mathrm{~mm}$ or greater induration was scored as a positive test.

\section{Clinical evaluation and biostatistical assessment}

Physical examinations and hematology blood tests were repeated at 2-week intervals and clinical chemistry blood tests at monthly intervals. Imaging studies were performed at baseline and at 12 weeks and 2 3 monthly thereafter. Pre- and post-treatment serum PSA values were obtained for all patients who were eligible for immunotherapeutical DC vaccination. Slopes of log-transformed serum PSA values were determined using a linear regression model (Prism 4, Graphpad Software, Inc.). PSA doubling time $($ PSADT) was calculated as $[\ln (2) \times \log (e) /$ slope $]$. For negative values (PSA half-life), PSADT was arbitrarily set to $>1$ year.

\section{IFN- $\gamma$ ELISPOT assay}

Antigen-specific $\mathrm{T}$ cell responses in PBMC were determined by using commercially available human IFN- $\gamma$ ELISPOT PVDF-Enzymatic kit (Diaclone, Besançon, France) according to the manufacturer's protocol. In brief, thawed PBMC from time points as indicated in Fig. 2 were incubated overnight in DMEM medium containing 1\% HEPES and 10\% AB serum, then washed and seeded at $2 \times 10^{5}$ cells per well into 96-well ELISPOT plates pre-coated with anti human IFN- $\gamma$ capture antibody and supplemented without or with the respective antigenic peptides at a final concentration of $10 \mu \mathrm{g} / \mathrm{ml}$ in RPMI medium containing $1 \%$ HEPES and $10 \%$ heat inactivated FCS. The plates were incubated at $37^{\circ} \mathrm{C}$ and production of IFN- $\gamma$ was detected after $20 \mathrm{~h}$ using biotinylated anti-IFN- $\gamma$ detection antibody, streptavidinalkaline phosphatase conjugate and BCIP/NBT as a substrate. The number of IFN- $\gamma$ producing cells was counted using AID ELISPOT Reader System (Autoimmun Diagnostika, Strassberg, Germany). Antigenspecific spots were calculated by subtraction of spots in the background wells (PBMC without Ag) from the total spots. All experiments were performed in duplicate wells and results were shown as the mean \pm SEM of duplicate measurements.
Detection of antigen-specific $\mathrm{CD}^{+} \mathrm{T}$ cells by $\mathrm{MHC}$ class I peptide multimer staining

PBMC collected on week 20 after the initiation of vaccination were restimulated in vitro for 1 week. For restimulation, DC of vaccinated CaP patients were pulsed with $10 \mu \mathrm{g} / \mathrm{ml}$ of FluM $_{58-66}$ or PSCA $_{14-22}$ peptide for $2 \mathrm{~h}$ at $37^{\circ} \mathrm{C}$. After washing, $5 \times 10^{5}$ peptide-pulsed DC were coincubated with $5 \times 10^{6}$ autologous PBMC in $2 \mathrm{ml}$ of DMEM medium supplemented with 1\% HEPES and $10 \% \mathrm{AB}$ serum for 7 days at $37^{\circ} \mathrm{C}$. Cells were stained with $\operatorname{Pro}^{\mathrm{TM}}$ Flu-pentamer-PE F2B-G specific to Flu peptide (Proimmune Ltd., Oxford, UK) or with PSCAtetramer-PE specific to PSCA peptide (a kind gift of Dr. Brendan Classon, Avidex Ltd., Abingdon, UK) and costained with FITC-labeled anti-human CD8 mAb (Immunotech, Berlin, Germany) for flow cytometry. The percentage of relevant antigen-specific cells in the CD8 ${ }^{+}$ $\mathrm{T}$ cell compartment were analyzed in the pre-gated lymphocyte population using CellQuest software.

\section{Cytotoxicity assay}

For restimulation of peptide-specific cytotoxic T lymphocytes (CTL) obtained on week 20 after the initiation of vaccination, $\mathrm{DC}$ of vaccinated $\mathrm{CaP}$ patients were pulsed with $10 \mu \mathrm{g} / \mathrm{ml}$ of FluM $\mathrm{M}_{58-66}$ or $\mathrm{PSCA}_{14-22}$ peptide for $2 \mathrm{~h}$ at $37^{\circ} \mathrm{C}$. After washing, $5 \times 10^{5}$ peptide-pulsed DC were coincubated with $5 \times 10^{6}$ autologous PBMC in $2 \mathrm{ml}$ of DMEM medium supplemented with $1 \%$ HEPES and $10 \%$ AB serum for 7 days at $37^{\circ} \mathrm{C}$. FluM ${ }_{58-66}$ or PSCA $_{14-22}$ peptide-pulsed $(10 \mu \mathrm{g} / \mathrm{ml}$ for $1 \mathrm{~h})$ or untreated T2 target cells were labeled with ${ }^{51} \mathrm{Cr}$ for $1 \mathrm{~h}$ at $37^{\circ} \mathrm{C}$. After washing, labeled target cells $(2,000$ cells in $100 \mu \mathrm{l})$ were added to various numbers of effector cells in round-bottom 96-well microplates. Chromium release was measured in supernatants $(100 \mu \mathrm{l})$ after $4 \mathrm{~h}$ of incubation at $37^{\circ} \mathrm{C}$. Percent-specific lysis was calculated as (experimental-spontaneous release)/(total-spontaneous release $) \times 100$. In some experiments, HLA$\mathrm{A}^{*} 0201^{+} \mathrm{PSCA}^{+} \mathrm{LNCaP}$ or HLA-A ${ }^{*} 0201^{-} \mathrm{PSCA}^{+}$PC3 cells were used as target cells.

\section{Results}

\section{DC treatment}

Quality control for DC vaccines is mandatory in order to obtain reproducible and comparable study results [21]. DC prepared according to our protocols from hormone-ablated patients were negative for bacterial or fungal contaminations, showed a purity of $>85 \%$ and were functionally not impaired, as described previously [19]. Maturation of DC induced the typical mature DC phenotype $\left(\mathrm{CD} 11 \mathrm{c}^{+}, \mathrm{CD} 40^{+}, \mathrm{CD} 80^{+}, \mathrm{CD}^{+} 3^{+}\right.$, $\mathrm{CD}^{+} 6^{+}, \mathrm{HLA}_{-\mathrm{DR}}{ }^{+}, \mathrm{CCR}^{+}{ }^{+}$, CD $14^{-}, \mathrm{CD} 16^{-}, \mathrm{CD}_{20}^{-}$, DC-SIGN ${ }^{-}, \mathrm{MNR}^{\text {low }}$ ) (Fig. 1a). In addition, efficient 
maturation of DC of all patients is indicated by responsiveness to the CCR7 ligands CCL19 and CCL21 (Fig. 1b).

Application of high dose steroids for suspected spinal cord compression in an outside hospital resulted in early withdrawal of patient 07 , severe pyelonephritis was the reason for early withdrawal of patient 24. Patient 07 received four vaccinations, and patient 24 was treated three times. Four patients completed at least six vaccinations and were therefore considered assessable for immunological responses. Three patients (P04, P12, and P16) showed significant antitumor immune responses after six vaccinations, whereas the treatment of P09 was discontinued due to the lack of general immune reactivity against the vaccine.

\section{Immune monitoring}

To evaluate the immune responses generated in vaccinated patients, we used ex vivo IFN- $\gamma$ ELISPOT assay, MHC class I peptide multimer staining and cytotoxicity assays as immune monitoring methods. Patients P12, $\mathrm{P} 16$ and $\mathrm{P} 04$ demonstrated specific $\mathrm{T}$ cell responses in PBMC to all antigens as determined by ELISPOT analysis (Fig. 2). The immune responses to the control antigens TT and FluM peptide and the tumor antigens were at baseline level before vaccination [see the leftmost columns (week 0) in Fig. 2] but became detectable after three rounds of vaccination, although the early prostatespecific $\mathrm{T}$ cell responses appeared to be slightly lower compared to the anti-influenza memory response. The maximal level of immune responsiveness against the tumor antigens was maintained for approximately 5 months in P12 and P16, whereas the maximal immune responsiveness was reached in P04 only after 8 months, i.e., after 11 vaccinations.

Direct ex vivo MHC class I multimer analysis was not feasible in these patients due to the low frequency of tumor antigen-specific CTL (not shown). However, MHC class I multimer-specific CTL became detectable following in vitro restimulation for 7 days (Fig. 3a). These CTL demonstrated strong in vitro cytotoxicity for T2 cells loaded with the respective peptide (Fig. 3b). Furthermore, in vitro restimulated CTL from P12 and P16 demonstrated significant PSCA-specific cytotoxicity against the $\mathrm{HLA}-\mathrm{A}^{*} 0201^{+} \mathrm{LNCaP}$ cell line, whereas HLA-A*0201 ${ }^{-}$and PSCA ${ }^{+}$PC3 cells were not recognized by the patient's CTL (Fig. 3c). External loading of LNCaP cells with the PSCA $14-22$ peptide did not further increase cytolysis which suggests that the low level of PSCA expressed in LNCaP and the low level of HLAA*0201 cell surface expression on this prostate carcinoma line were sufficient for recognition by patient-de-
Fig. 1 Phenotype of DC generated from PBMC of patients with hormonerefractory prostate carcinoma. a Representative surface molecule expression pattern of mature DC from P12. DC were collected after $48 \mathrm{~h}$ activation with proinflammatory

cytokines and stained with the indicated $\mathrm{mAbs}$ for phenotypic analysis with flow cytometry (filled histograms), respectively. Open line histograms represent stainings with isotype matched control antibodies. b In vitro migration capacity of matured DC. Matured DC were tested for CCR7-dependent migration towards CCL19 (dark gray bars) and CCL21 (light gray bars). Medium without cytokines was used to record spontaneous migration (open bars). The percentage of migrated DC was calculated as the mean \pm SEM of duplicate measurements
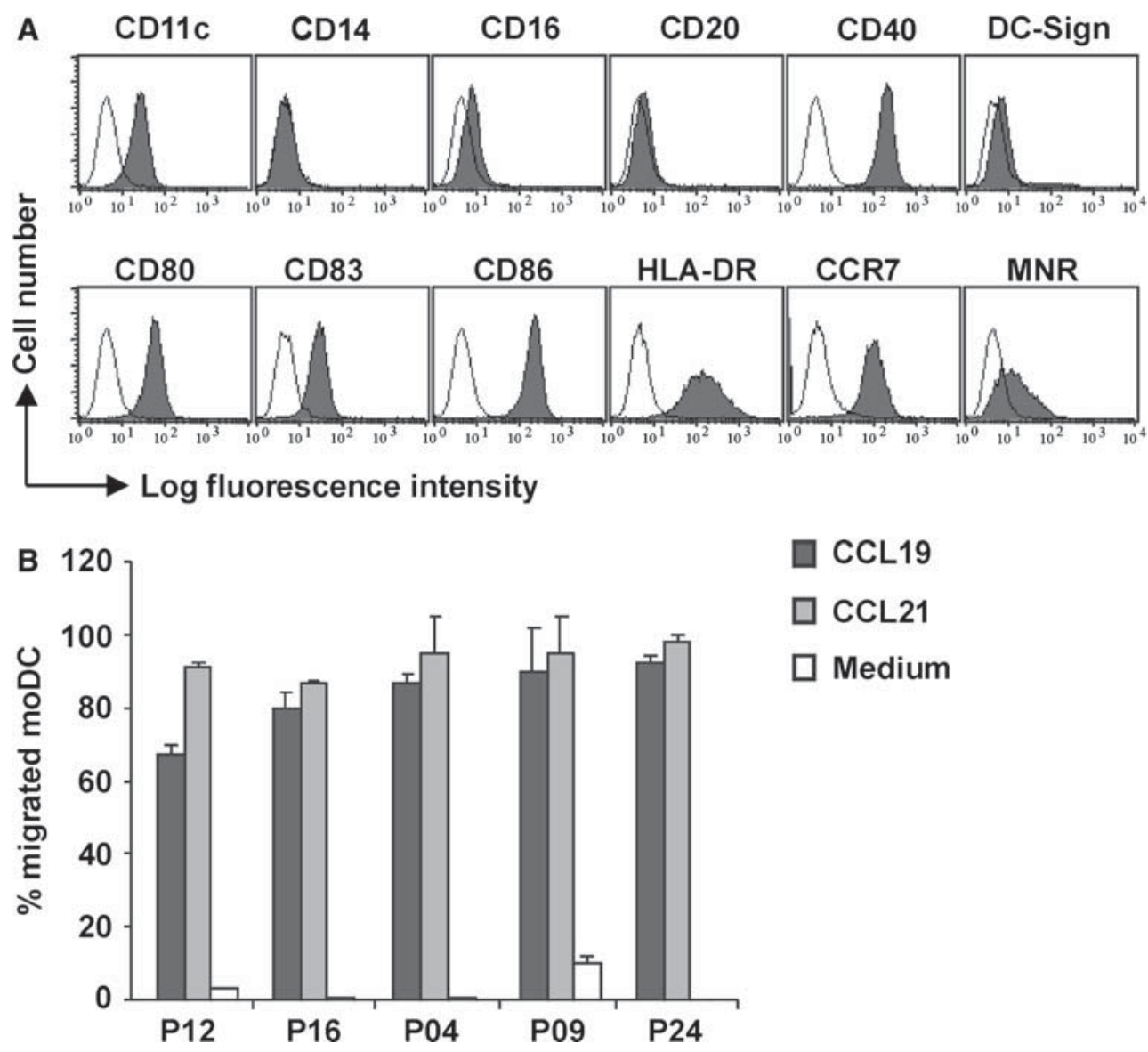

CCL19

CCL21

Medium 

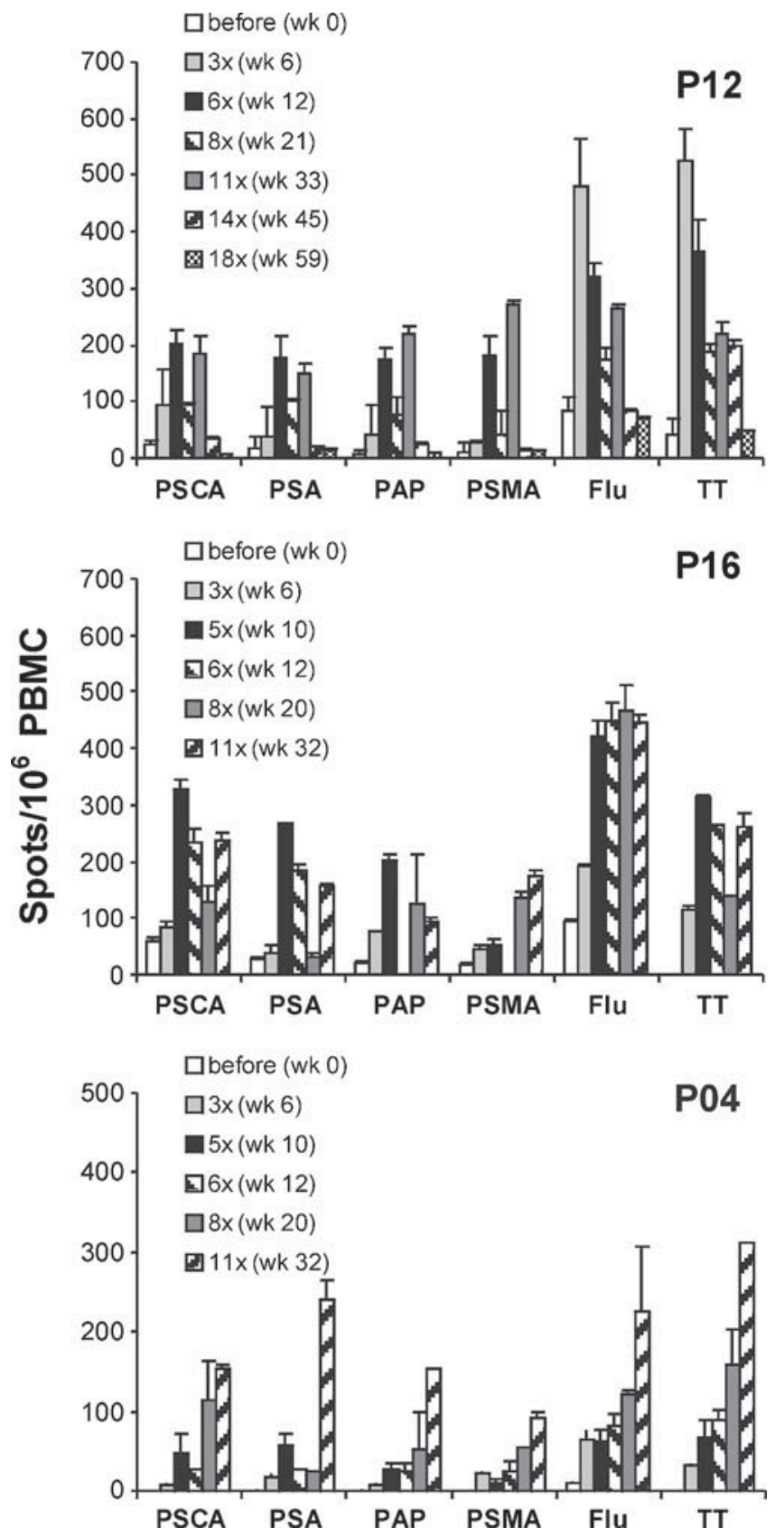

Fig. $2 \mathrm{~T}$ cell responses of three patients (P04, P12, and P16) to prostate and control antigens as determined by ELISPOT analysis. ELISPOT assays were performed with PBMC obtained at the time points indicated within the panels. Shown are the number of spots per $10^{6}$ PBMC obtained in the presence of indicated peptides $\mathrm{PSCA}_{14-22}$ (PSCA), $\mathrm{PAP}_{299-307}(P A P), \mathrm{PSMA}_{4-12}$ (PSMA), $\mathrm{PSA}_{154-163}(P S A)$, influenza matrix ${ }_{58-66}(F l u)$ or tetanus toxoid (TT) after subtraction of the number of spots obtained with the same PBMC in the absence of antigen. The values represent the mean of duplicates \pm SEM

rived CTL. Taken together, these results indicate that - despite peptide competition for binding to the same MHC molecule-DC loaded with multiple prostate cancer peptides can induce significant antitumor CTL responses in these tumor patients.
Safety

Repeated DC vaccination was not associated with renal, hematologic, hepatic, cardiac, pulmonary, neurologic or autoimmune side effects. Grade 1 or 2 erythema and induration after vaccination was found in all patients except one (non-responder P09). One patient reported about grade 1 nausea after vaccination, a second patient had slightly elevated temperatures for 2 days after the vaccination $\left(<38.0^{\circ} \mathrm{C}\right)$.

\section{DTH reactions}

DTH reactions were found after the third and the fifth vaccination in patients $\mathrm{P} 04, \mathrm{P} 12$, and $\mathrm{P} 16$. The reactions occurred both to antigen-loaded DC (FluM/TT and PSCA/PSA/PAP/PSMA mix), but also to unpulsed DC. A significant difference between the response against antigen-loaded and control DC could not be recorded with this method.

\section{Clinical response}

Changes in PSA values were used to monitor the clinical response, since the reported patients did not have measurable disease. Our immune monitoring indicated that significant DC-induced antitumor responses require repeated injections and built-up rather slowly in 810 weeks (Fig. 2). We therefore calculated PSA slopes and doubling times for the initial treatment phase, i.e., weeks $0-10$ including a phase of $6-10$ weeks before the treatment, and the following "maintenance" phase. The initial PSADT (range 7.0-12.2 weeks) was prolonged for all three immunologically responding patients with P16 showing even a negative PSA slope (Fig. 4).

Despite the positive trends in PSADT, all patients eventually had progressive disease and the vaccination was discontinued. P04 presented with rapidly rising PSA values between week 34 and 38 of his treatment, P12 developed a new soft tissue metastasis and P16 presented with a new metastasis in the adrenal gland. All three long-term vaccinated patients were still alive in November 2005, i.e., 21 (P04), 27 (P12), and 25 (P16) months after inclusion into the trial.

\section{Discussion}

The discovery and identification of tumor-associated antigens has facilitated specific targeting of malignant cells by antibodies or CTL [22]. According to the immunosurveillance theory [23], antitumor vaccination represents a boost for pre-existing immune responses against a particular set of tumor antigens. However, tumor cells constantly change their phenotype, i.e., they become less immunogenic under immune-mediated 
Fig. 3 In vitro restimulation of antigen-specific CTL obtained from patients after the eighth vaccination and assessment of functional activity. a MHC class I peptide-multimer staining after in vitro restimulation of PBMC of the indicated vaccinated patients. PBMC were restimulated for 7 days with FluM or PSCA peptides, respectively. Values in the upper right quadrant of the dot plot indicate the percentage of multimer-binding CD8 lymphocytes. The data represent one of three independent experiments with similar results. b Cytotoxic activity of FluM and PSCAspecific CTL, which were stimulated as described in a was determined in ${ }^{51} \mathrm{Cr}$ release assays using $\mathrm{T} 2$ cells as peptidelabeled (closed symbols) or unpulsed (open symbols) target cells. c Cytotoxicity of PSCAspecific CTL to human prostate carcinoma cells. PSCA-specific CTL obtained in two

vaccinated patients after one cycle of in vitro restimulation as described in a were tested for their ability to lyse human prostate carcinoma cell lines $\mathrm{LNCaP}\left(H L A-A^{*} 0201^{+}\right.$and $\left.P S C A^{+}\right)$or PC3 ( $H L A-$ $A^{*} 0201^{-}$and $\left.P S C A^{+}\right)$. LNCaP and $\mathrm{PC} 3$ cells were either pulsed with exogenous PSCA or control peptide Flu (for $L N C a P$ only), or were left without peptide pulse. Experiments were performed at an effector/target cell ratio of 30:1. Pooled data from two independent experiments are represented as mean $\pm \mathrm{SEM}$
A
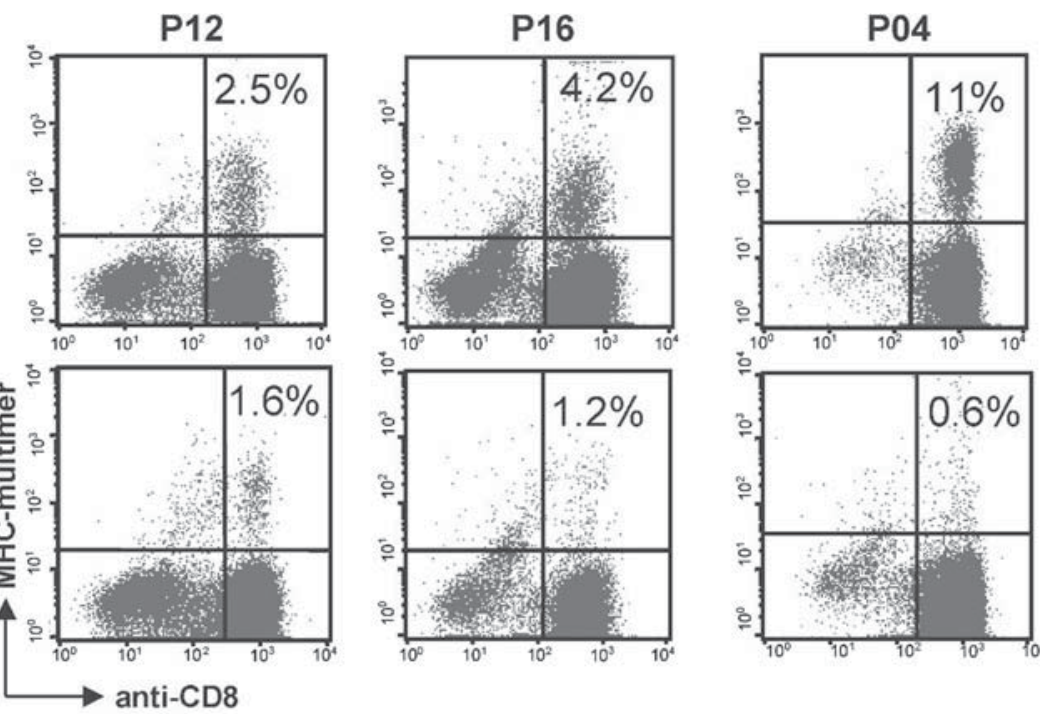

Flu

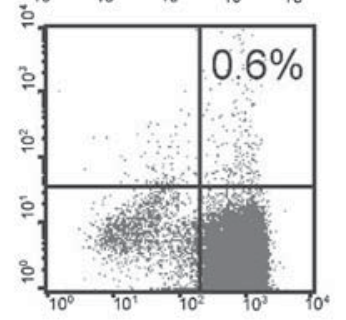

PSCA
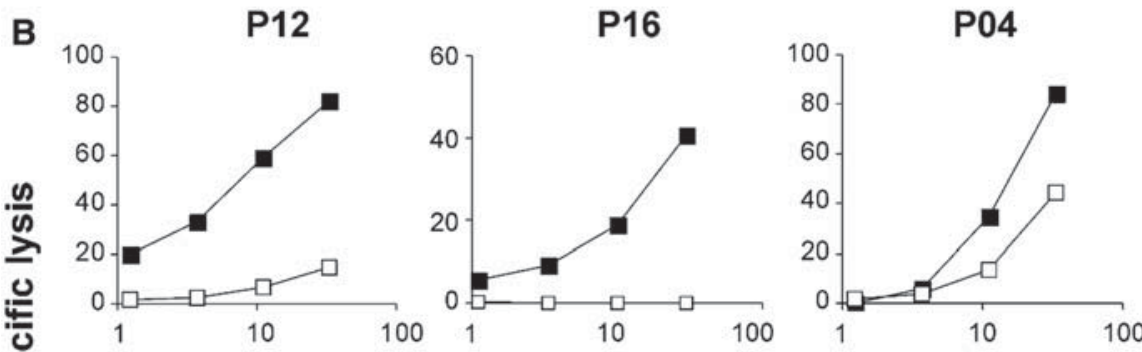

Flu
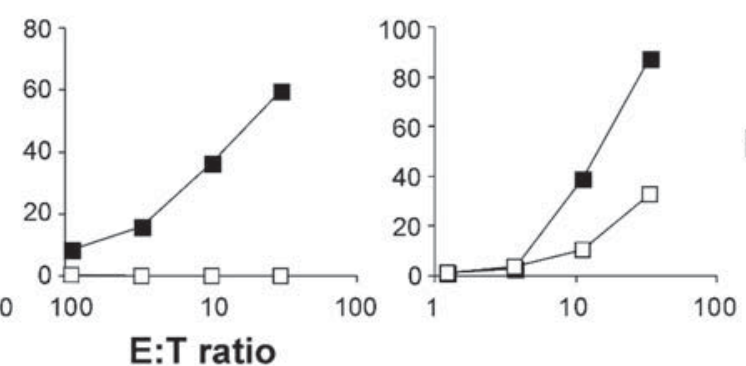

PSCA
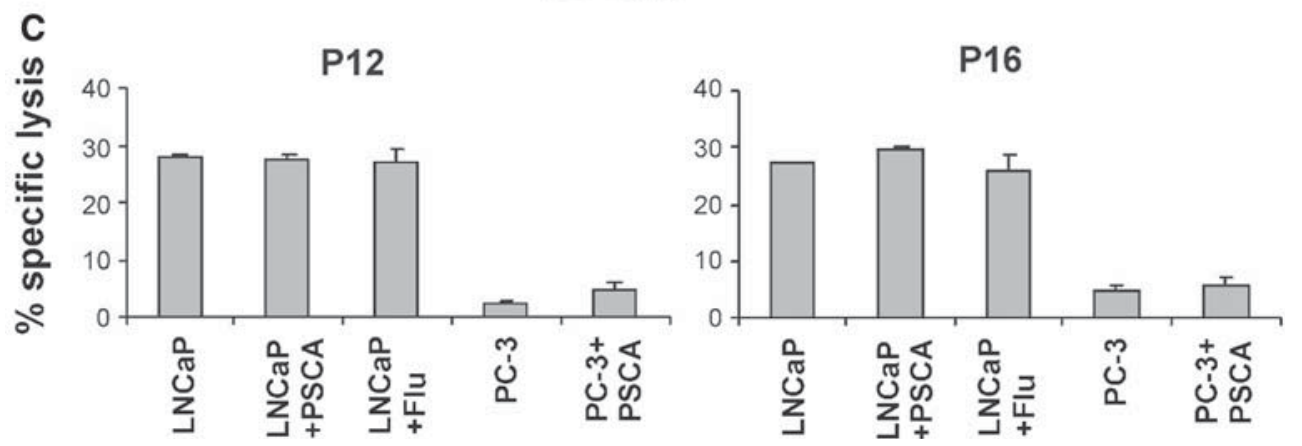

selection pressure and, vice versa, gain immunogenicity in the absence of immune selection. The interplay between immunosurveillance and immune escape has been termed "tumor immunoediting" [24]. Tumors may evade immune recognition by several means including $\mathrm{MHC}$ class I down-regulation, escaping death receptor signaling, impediment of antigen processing, or downregulation of target antigens (reviewed in [13, 25]).
Antigen loss may be even promoted during immunotherapy as shown by Yee et al. [26] who observed the emergence of Mart- $1^{-}$melanoma metastasis following adoptive transfer of Mart-1-specific $T$ cells. Similar findings have been reported during DC-based immunotherapy [27]. Concomitant targeting of multiple tumor antigens represents one strategy to counteract immune evasion during immunotherapy. 

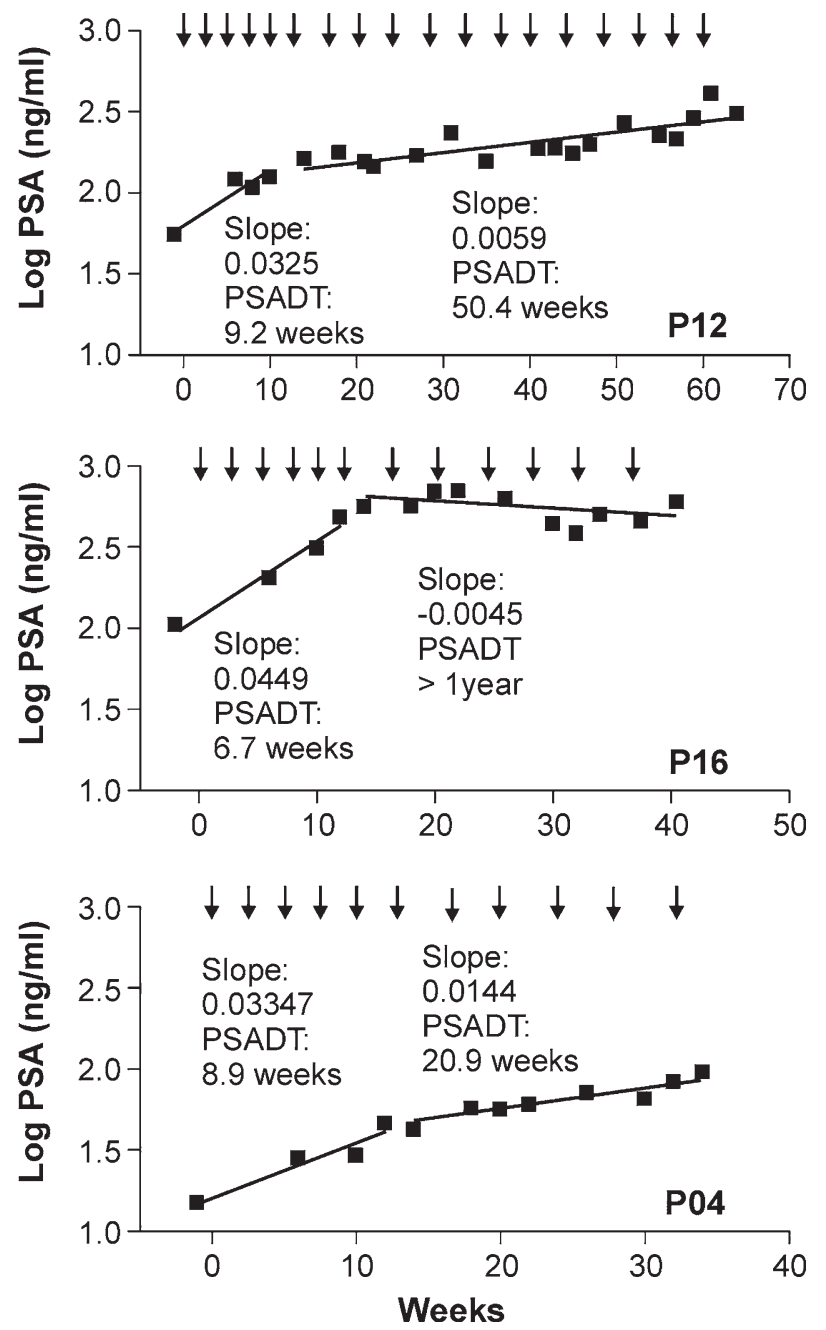

Fig. 4 Clinical responses in DC vaccinated patients determined by serial PSA measurements. Linear regression of log-transformed PSA values was used to determine the slopes. PSADT was calculated as indicated in Patients, materials and methods. Arrows indicate time point of vaccination

The presented study assessed the feasibility and immunological efficacy of DC-based multi-epitope vaccination in prostate cancer. In previous clinical studies, DC had been loaded with peptides, proteins, or mRNA derived from single prostate-specific antigens (reviewed in [28]). The results of our study indicate that DC possess high loading and presentation capacity for multiple tumor antigens: HLA-A*0201-binding peptides derived from the prostate-specific antigens PSCA, PSA, PAP, and PSMA were pulsed on DC. Our immune monitoring revealed first, that the maximal $\mathrm{T}$ cell immune responses against the four prostate-specific peptides were in an equal range, and second, that the maximal $\mathrm{T}$ cell response against the tumor antigens was only 30-50\% lower than the response against the FluM control peptide. Furthermore, it is noteworthy that the kinetics of the induced antitumor $\mathrm{T}$ cell responses did not differ significantly from the anti-influenza recall response (see Fig. 2). Taken together, this small initial study indicates that simultaneous pulsing of multiple tumor-specific peptides on one DC population generates a vaccine capable of inducing broad antitumor $\mathrm{T}$ cell responses.

Antigenic stimulation of CTL leads to the induction of a well-ordered differentiation program defining naive, effector, effector memory, and central memory $\mathrm{T}$ cell populations [15, 29]. However, optimal restimulation of CTL during the memory phase is required to maintain high CTL frequencies and activity. Recent studies have shown that re-introduction of antigen via $\mathrm{DC}$ is most efficient in maintaining CTL responses [16, 17]. Since growing tumors are only effectively controlled if a continuous immune pressure by activated CTL is maintained [30, 31], repeated injections of DC are mandatory for DC-based immunotherapies. We addressed here the question whether repeated boosting of DC-induced CTL responses in prostate cancer patients can be maintained for more than 6 months. In two of the three long-term vaccinated patients (P12 and P16), CTL responses as determined by IFN- $\gamma$ production remained stable for at least 32 weeks, while P12 showed a striking decline in the responsiveness against both tumor and control antigens from week 45 onwards (Fig. 2). In contrast, CTL responses in P04 increased continuously over the vaccination period. The reason for the different response pattern in the patients remains so far elusive. We have tested whether an accumulation or loss of CD $4{ }^{+} \mathrm{CD} 25^{+}$ regulatory $\mathrm{T}$ (Treg) cells is associated with the long-term decrease or the increase of DC-induced CTL responses in these patients, but the results have not been conclusive. Since the emergence of Treg has been shown in the context of repetitive in vitro stimulation of human $\mathrm{T}$ cells [32], it will be of importance to clarify this issue in future studies.

In order to further characterize the function of the generated CTL, we used PBMC from week 20 after the onset of vaccination for one round of in vitro restimulation with the PSCA and Flu peptides followed by MHC multimer staining and cytolytic assays (Fig. 3). We found that CTLs from three patients potently lysed target cells loaded with PSCA and Flu peptides but it should be pointed out that the numbers of MHC multimer stained cells did not correlate with the cytolytic activity as has been reported previously [33]. Neverthless, lysis of LNCaP prostate carcinoma cells which express low levels of PSCA antigen and low amounts of HLA-A0201 on the cell surface was readily achieved (Fig. 3c).

As shown in the previous studies (summarized in [28]), the DC vaccination approach, even if boosting is performed for $>6$ months, is essentially free of side effects. It is noteworthy that DTH reactions in the patients were not only directed against antigen-pulsed, but also against unpulsed DC indicating that the in vitro cultured DC possess a strong sensitizing capacity against DCassociated self-antigens. The use of DTH reactions as a measure for immunological responsiveness was therefore abandoned in this study. Also other DC-based trials of immunotherapy against prostate cancer have not used 
DTH measurement as a read out system for an antigenspecific immune response [7-12, 34-38]. Only in one study DTH was used as an assessment of general immune status for recall antigens [34] and in a second study to compare two different antigen formulations [12].

Since significant immunological responses against the tumor antigens became detectable only following $>5$ injections, we compared the PSADT changes between the first 10 weeks of treatment and the period of monthly booster injections. All long-term treated patients reacted with an increase in PSADT which correlated with the onset of IFN- $\gamma$ production by CTL from the peripheral blood after the sixth vaccination. Our data nourish the notion that only after repeated DCbased vaccinations over several months, an effect on the progression of PSA values can be expected as has previously been suggested by Murphy et al. [34]. It should also be noticed that the PSA value did not respond to transient changes in the IFN $-\gamma$ response as was observed for patient P16 on week 20 (Fig. 2). Clinical progression, however, was not halted since the patients developed new metastases. Based on the evidence from experimental models, it is rather unlikely that even a sufficiently stimulated immune system will win the uphill struggle against an established rapidly growing tumor $[30,39,40]$. It is thus likely that treating patients with earlier disease stages may not only result in successful vaccination but also in clear clinical benefits for the patients. Therefore, clinical trials in an adjuvant setting for patients with minimal residual disease would be warranted.

Acknowledgements We thank R. Steingruber for clinical assistance and Dr. Gennady Bocharov for help with biostatistical calculations. We thank Dr. J. Hering and the personnel from the regional blood donation center SRC. Dr. Brendan Classon in Avidex Ltd., Abingdon, UK is acknowledged for providing PSCA tetramers.

\section{References}

1. Jones GW, Mettlin C, Murphy GP, Guinan P, Herr HW, Hussey DH, Chmiel JS, Fremgen AM, Clive RE, Zuber-Ocwieja KE (1995) Patterns of care for carcinoma of the prostate gland: results of a national survey of 1984 and 1990. J Am Coll Surg 180:545-554

2. Tannock IF, de Wit R, Berry WR, Horti J, Pluzanska A, Chi KN, Oudard S, Theodore C, James ND, Turesson I, Rosenthal MA, Eisenberger MA (2004) Docetaxel plus prednisone or mitoxantrone plus prednisone for advanced prostate cancer. $\mathrm{N}$ Engl J Med 351:1502-1512

3. Petrylak DP, Tangen CM, Hussain MH, Lara PN Jr, Jones JA, Taplin ME, Burch PA, Berry D, Moinpour C, Kohli M, Benson MC, Small EJ, Raghavan D, Crawford ED (2004) Docetaxel and estramustine compared with mitoxantrone and prednisone for advanced refractory prostate cancer. $\mathbf{N}$ Engl $\mathbf{J}$ Med 351:1513-1520

4. Markiewicz M, Kast WM (2003) Advances in immunotherapy for prostate cancer. Adv Cancer Res 87:159-194

5. Tjoa BA, Simmons SJ, Elgamal A, Rogers M, Ragde H, Kenny GM, Troychak MJ, Boynton AL, Murphy GP (1999) Followup evaluation of a phase II prostate cancer vaccine trial. Prostate 40:125-129
6. Lodge PA, Jones LA, Bader RA, Murphy GP, Salgaller ML (2000) Dendritic cell-based immunotherapy of prostate cancer: immune monitoring of a phase II clinical trial. Cancer Res 60:829-833

7. Heiser A, Coleman D, Dannull J, Yancey D, Maurice MA, Lallas CD, Dahm P, Niedzwiecki D, Gilboa E, Vieweg J (2002) Autologous dendritic cells transfected with prostate-specific antigen RNA stimulate CTL responses against metastatic prostate tumors. J Clin Invest 109:409-417

8. Burch PA, Breen JK, Buckner JC, Gastineau DA, Kaur JA, Laus RL, Padley DJ, Peshwa MV, Pitot HC, Richardson RL, Smits BJ, Sopapan P, Strang G, Valone FH, Vuk-Pavlovic S (2000) Priming tissue-specific cellular immunity in a phase I trial of autologous dendritic cells for prostate cancer. Clin Cancer Res 6:2175-2182

9. Small EJ, Fratesi P, Reese DM, Strang G, Laus R, Peshwa MV, Valone FH (2000) Immunotherapy of hormone-refractory prostate cancer with antigen-loaded dendritic cells. J Clin Oncol 18:3894-3903

10. Fong L, Brockstedt D, Benike C, Breen JK, Strang G, Ruegg CL, Engleman EG (2001) Dendritic cell-based xenoantigen vaccination for prostate cancer immunotherapy. J Immunol 167:7150-7156

11. Vonderheide RH, Domchek SM, Schultze JL, George DJ, Hoar KM, Chen DY, Stephans KF, Masutomi K, Loda M, Xia Z, Anderson KS, Hahn WC, Nadler LM (2004) Vaccination of cancer patients against telomerase induces functional antitumor $\mathrm{CD}^{+} \mathrm{T}$ lymphocytes. Clin Cancer Res $10: 828-839$

12. Su Z, Dannull J, Yang BK, Dahm P, Coleman D, Yancey D, Sichi S, Niedzwiecki D, Boczkowski D, Gilboa E, Vieweg J (2005) Telomerase mRNA-transfected dendritic cells stimulate antigen-specific $\mathrm{CD} 8{ }^{+}$and $\mathrm{CD} 4^{+} \mathrm{T}$ cell responses in patients with metastatic prostate cancer. J Immunol 174:3798-3807

13. Ahmad M, Rees RC, Ali SA (2004) Escape from immunotherapy: possible mechanisms that influence tumor regression/ progression. Cancer Immunol Immunother 53:844-854

14. Johnsen AK, Templeton DJ, Sy M, Harding CV (1999) Deficiency of transporter for antigen presentation (TAP) in tumor cells allows evasion of immune surveillance and increases tumorigenesis. J Immunol 163:4224-4231

15. Sallusto F, Geginat J, Lanzavecchia A (2004) Central memory and effector memory $\mathrm{T}$ cell subsets: function, generation, and maintenance. Annu Rev Immunol 22:745-763

16. Ludewig B, Oehen S, Barchiesi F, Schwendener RA, Hengartner H, Zinkernagel RM (1999) Protective antiviral cytotoxic $\mathrm{T}$ cell memory is most efficiently maintained by restimulation via dendritic cells. J Immunol 163:1839-1844

17. Zammit DJ, Cauley LS, Pham QM, Lefrancois L (2005) Dendritic cells maximize the memory $\mathrm{CD} 8 \mathrm{~T}$ cell response to infection. Immunity 22:561-570

18. Krausa P, Brywka M III, Savage D, Hui KM, Bunce M, Ngai JL, Teo DL, Ong YW, Barouch D, Allsop CE (1995) Genetic polymorphism within HLA-A*02: significant allelic variation revealed in different populations. Tissue Antigens 45:223-231

19. Waeckerle-Men Y, Allmen EU, von Moos R, Classon BJ, Scandella E, Schmid HP, Ludewig B, Groettrup M, Gillessen S (2005) Dendritic cells generated from patients with androgenindependent prostate cancer are not impaired in migration and T-cell stimulation. Prostate 64:323-331

20. Waeckerle-Men Y, Scandella E, Uetz-Von Allmen E, Ludewig B, Gillessen S, Merkle HP, Gander B, Groettrup M (2004) Phenotype and functional analysis of human monocyte-derived dendritic cells loaded with biodegradable poly(lactide-co-glycolide) microspheres for immunotherapy. J Immunol Methods 287:109-124

21. Figdor CG, de Vries IJ, Lesterhuis WJ, Melief CJ (2004) Dendritic cell immunotherapy: mapping the way. Nat Med $10: 475-480$

22. Pardoll DM (2002) Spinning molecular immunology into successful immunotherapy. Nat Rev Immunol 2:227-238 
23. Burnet M (1957) Cancer: a biological approach. III. Viruses associated with neoplastic conditions. IV. Practical applications. Br Med J (5023):841-847

24. Dunn GP, Bruce AT, Ikeda H, Old LJ, Schreiber RD (2002) Cancer immunoediting: from immunosurveillance to tumor escape. Nat Immunol 3:991-998

25. Mapara MY, Sykes M (2004) Tolerance and cancer: mechanisms of tumor evasion and strategies for breaking tolerance. $\mathbf{J}$ Clin Oncol 22:1136-1151

26. Yee C, Thompson JA, Byrd D, Riddell SR, Roche P, Celis E, Greenberg PD (2002) Adoptive T cell therapy using antigenspecific $\mathrm{CD} 8^{+} \mathrm{T}$ cell clones for the treatment of patients with metastatic melanoma: in vivo persistence, migration, and antitumor effect of transferred T cells. Proc Natl Acad Sci USA 99:16168-16173

27. Thurner B, Haendle I, Roder C, Dieckmann D, Keikavoussi P, Jonuleit H, Bender A, Maczek C, Schreiner D, von Den Driesch P, Brocker EB, Steinman RM, Enk A, Kampgen E, Schuler G (1999) Vaccination with mage-3A1 peptide-pulsed mature, monocyte-derived dendritic cells expands specific cytotoxic $\mathrm{T}$ cells and induces regression of some metastases in advanced stage IV melanoma. J Exp Med 190:1669-1678

28. Ragde H, Cavanagh WA, Tjoa BA (2004) Dendritic cell based vaccines: progress in immunotherapy studies for prostate cancer. J Urol 172:2532-2538

29. Kaech SM, Wherry EJ, Ahmed R (2002) Effector and memory T-cell differentiation: implications for vaccine development. Nat Rev Immunol 2:251-262

30. Ochsenbein AF, Klenerman P, Karrer U, Ludewig B, Pericin M, Hengartner H, Zinkernagel RM (1999) Immune surveillance against a solid tumor fails because of immunological ignorance. Proc Natl Acad Sci USA 96:2233-2238

31. Ludewig B, Ochsenbein AF, Odermatt B, Paulin D, Hengartner H, Zinkernagel RM (2000) Immunotherapy with dendritic cells directed against tumor antigens shared with normal host cells results in severe autoimmune disease. J Exp Med 191:795804

32. Jonuleit H, Schmitt E, Schuler G, Knop J, Enk AH (2000) Induction of interleukin 10-producing, nonproliferating $\mathrm{CD} 4^{(+)}$ $\mathrm{T}$ cells with regulatory properties by repetitive stimulation with allogeneic immature human dendritic cells. J Exp Med 192:1213-1222
33. Betts MR, Price DA, Brenchley JM, Lore K, Guenaga FJ, Smed-Sorensen A, Ambrozak DR, Migueles SA, Connors M, Roederer M, Douek DC, Koup RA (2004) The functional profile of primary human antiviral $\mathrm{CD} 8^{+} \mathrm{T}$ cell effector activity is dictated by cognate peptide concentration. J Immunol 172:6407-6417

34. Murphy GP, Tjoa BA, Simmons SJ, Jarisch J, Bowes VA, Ragde H, Rogers M, Elgamal A, Kenny GM, Cobb OE, Ireton RC, Troychak MJ, Salgaller ML, Boynton AL (1999) Infusion of dendritic cells pulsed with HLA-A2-specific prostate-specific membrane antigen peptides: a phase II prostate cancer vaccine trial involving patients with hormone-refractory metastatic disease. Prostate 38:73-78

35. Burch PA, Croghan GA, Gastineau DA, Jones LA, Kaur JS, Kylstra JW, Richardson RL, Valone FH, Vuk-Pavlovic S (2004) Immunotherapy (APC8015, Provenge ${ }^{\circledR}$ ) targeting prostatic acid phosphatase can induce durable remission of metastatic androgen-independent prostate cancer: a phase 2 trial. Prostate 60:197-204

36. Barrou B, Benoît G, Ouldkaci M, Cussenot O, Salcedo M, Agrawal S, Massicard S, Bercovici N, Ericson ML, Thiounn N (2004) Vaccination of prostatectomized prostate cancer patients in biochemical relapse, with autologous dentritic cells pulsed with recombinant human PSA. Cancer Immunol Immunother 53:453-460

37. Pandha HS, John RJ, Hutchinson J, James N, Whelan M, Corbishley C, Dalgleish AG (2004) Dendritic cell immunotherapy for urological cancers using cryopreserved allogeneic tumour lysate-pulsed cells: a phase I/II study. BJU Int 94:412418

38. Fuessel S, Meye A, Schmitz M, Zastrow S, Linne C, Richter K, Lobel B, Hakenberg OW, Hoelig K, Rieber EP, Wirth MP (2006) Vaccination of hormone-refractory prostate cancer patients with peptide cocktail-loaded dendritic cells: Results of a phase I clinical trial. Prostate (epub ahead of print)

39. Prehn RT, Main JM (1957) Immunity to methyl-collanthreneinduced sarcomas. J Natl Cancer Inst 18:769-782

40. Speiser DE, Miranda R, Zakarian A, Bachmann MF, McKallFaienza K, Odermatt B, Hanahan D, Zinkernagel RM, Ohashi PS (1997) Self antigens expressed by solid tumors do not efficiently stimulate naive or activated $\mathrm{T}$ cells: implications for immunotherapy. J Exp Med 186:645-653 